\title{
Estimates of Heritabiliy, Genetic and Principlal Componente Analysis for Yield and its Traits in Ethiopian Mustard (Brasica Carinata A. Braun) Landraces
}

\author{
Fekadu Amsalu* \\ Holetta Agricultural Research Center P. O. Box 2003, Addis Ababa, Ethiopia
}

*Corresponding Authors: Fekadu Amsalu, Holetta Agricultural Research Center P. O. Box 2003, Addis

Ababa, Ethiopia

\begin{abstract}
The experiment was executed to estimate heritability genetic advance and principal component analysis for yield and its traits in Ethiopian mustard land races at Holetta agricultural research center, Ethiopia. Forty nine genotypes collected from different agro ecologies were analyzed using seed and agronomic traits in order to estimate heritability genetic advance and major principal component traits that exists in these materials. The experiment was carried out in a simple lattice design. The analysis of variance showed that there were significant differences among genotypes for all traits compared. The significant difference indicates the existence of high heritability, genetic advance among the accessions that is important for selection and breeding. The highest heritability in broad sense was recorded for thousand seed weight $(68.80 \%)$, followed by days to flowering (65.91\%), stand percent (63.14\%), days to maturity (60.43\%), plant height (59.63\%) and seed yield per plot (42.99\%) and primary branches (34.20\%). This suggests that large proportion of the total variance was due to the high genotypic and less environmental variance. Hence, a good progress can be made if some of these traits are considered as selection criteria for the improvement of yield and yield component traits. Principal component analysis showed that $88.18 \%$ of the variation was contributed by the first five principal components for agronomic traits. Days to flowering, days to maturity, plant height, primary branches and stand percent of plant were the major seed yield positive contributors of the variation in the first principal component in which $39.5 \%$ of the variation revealed. The present study revealed the presence of considerable high principal component contributor traits among genotypes for Leaf area, leaf length, leaf width, petiole length days to flowering and days to maturity traits analyzed. Therefore these traits can serve as selection indices in genetic improvement of mustard yield and its component traits.
\end{abstract}

Keywords: Ethiopian mustard, Genetic advance, heritability, Principal component analysis

\section{INTRODUCTION}

The genus Brassica of Brassicaceae family as a whole is believed to have originated around the Mediterranean, Eastern Afghanistan and the adjoing portion of Pakistan and North-Eastern Africa (Hemigway, 1976). The genus includes six economically important species, namely, Brassica rapa, B. oleracea, B. nigra, B. juncea, B. napus, and B. carinata (Doweny and Röbbelen, 1989). Ethiopian mustard is believed to be originated in the highlands of the Ethiopian plateau and the adjoining portion of East Africa and the Mediterranean coast (Gomez-Campo and Prakash, 1999). It evolved as a natural cross between B. nigra $(\mathrm{BB})(\mathrm{n}=8)$ and B. oleracea $(\mathrm{CC})(\mathrm{n}=9)$ and underwent further chromosomal doubling $(2 \mathrm{n}=34 ; \mathrm{UN}, 1935)$. It is partially amphidiploid.

In Ethiopia, among the highland oilseeds, Ethiopian mustard stands third next to niger seed and linseed in total production and areas coverage (CSA, 2013/2014). Its area and production are estimated to 44041.34 hectares and 62450.266 tons, respectively, at private peasants holdings level, with an average productivity of 1.418 tons/ha (CSA, 2013/14). It is often grown on well-drained and organic matter rich soils close to homesteads but the trend of growing far from their home is started by using inorganic fertilizer. Ethiopian mustard is well adapted to cool, long growing season and high rainfall areas at elevation between 2200 and 2800 meters. In these areas, the temperature and rainfall range from 12 to $18^{\circ} \mathrm{C}$ and 500 to $1200 \mathrm{~mm}$, respectively during the growing season (i.e., June to December). It grows well in either a heavy sandy loam or light clay soils with a good drainage system (Getinet and Nigussie, 1997). 
The crop is traditionally used for many purposes, such as greasing traditional bread-baking clay pan, curing certain diseases and as a source of vegetable relish (Nigussie, 2001). For the small-scale farmers, it is a security crop, because it is a source of food and income at the time of acute food and income shortage that mostly occurs at the middle of the main rainy season.

Major production constraints of the Ethiopian mustard are: lack of high yielding, early maturing varieties, high erucic acid (C22: 1) content in seed oil and high glucosinolate content in the meal (EARO, 2000). Crop improvement through successful selection program largely depends on the nature and magnitude of genetic variability present in the germplasm, Goyal and Kumar, (1991). The plant breeder needs to know the estimate of gene effects in order to plan for an effective breeding method for the improvement of the desired traits. Moreover, the type of breeding method to employ for the genetic improvement of yield and its components depends upon the type of gene action controlling the inheritance of the traits. Knowledge on the nature of the combining ability effects and their resulting variances, is the opening line in the preparation for breeding towards improvement of crop species. Therefore the present study was executed to estimate broad sense heritability genetic advance and principal component analysis for seed yield and its attributing traits in forty nine Ethiopian mustard land races

\section{Materials AND Methods}

\subsection{Experimental Site}

The experiment was conducted at Holetta Agricultural Research Center (HARC) in 2013/2014 cropping season from June to December 2013. Holetta (West Shewa Zone of Oromia Region) is located at latitude $9^{\circ} \mathrm{N}$ and longitude $38^{\circ} \mathrm{E}$, altitude of $2400 \mathrm{~m}$ a.s.l situated $30 \mathrm{~km}$ West of Addis Ababa. It is one of the representatives of oil seed Brassica growing areas in the central highlands of Ethiopia (Nigussie and Mesfin, 1994). The area has mean annual rainfall of $1059 \mathrm{~mm}$ and temperatures of $23^{\circ} \mathrm{C}$ (maximum) and $8^{\circ} \mathrm{C}$ (minimum). The soil type is Nitisols with soil ph in the range of $6.0-7.5$ (Nigussie and Mesfin, 1994).

\subsection{Description of Test Materials}

A total of forty-nine mustard land races that include one local check and one standard check were used in this study. The majority of the accessions represent the national collection from different major mustard growing regions of the country and that are maintained at HARC. The accessions were obtained kindly from Holetta agricultural research center of highland oil crops improvement project. The details of the accessions used in the experiment aare given in Table 1.

Table1. List of 49 Ethiopian mustard genotypes used in the study and their origin

\begin{tabular}{|l|c|l|l|l|l|l|}
\hline No. & Accession number & Area of collection & Altitude(m) & Latitude & Longitude \\
\hline 1 & PGRC/E 20001 & West Wollega/Arjo & 2420 & $08-44-00 \mathrm{~N}$ & $36-40.00 \mathrm{E}$ \\
\hline 2 & $"$ & 20002 & Bale Zone/Kitu & 2500 & $06-.59 .00 \mathrm{~N}$ & $39-12-00 \mathrm{E}$ \\
\hline 3 & $"$ & 20004 & South Gonder/Liba & 1980 & $12-.05-00 \mathrm{~N}$ & $37-44-00 \mathrm{E}$ \\
\hline 5 & $"$ & 20005 & SouthGonder/Debretabor & 1830 & $11-57-00 \mathrm{~N}$ & $37-37-00 \mathrm{E}$ \\
\hline 6 & $"$ & 20006 & South Gonder/Debretabor & 1980 & $11-50-00 \mathrm{~N}$ & $37-37 \_00 \mathrm{E}$ \\
\hline 7 & $"$ & 20007 & North Gonder/Woger/Dabat & 2500 & $*$ & $*$ \\
\hline 8 & $"$ & 20056 & West Gojiam/Awi /Dangila & 1980 & $11-.20-00 \mathrm{~N}$ & $36-58-00 \mathrm{E}$ \\
\hline 9 & $"$ & 20065 & West Shewa/Jibatenamecha & 2200 & $09-01-00 \mathrm{~N}$ & $38 .-20-00 \mathrm{E}$ \\
\hline 10 & $"$ & 20066 & West Shewa/Jibatena mecha & 2200 & $08-58-00 \mathrm{~N}$ & $37-30.00 \mathrm{E}$ \\
\hline 11 & $"$ & 20067 & West Shewa/Ambo & 1950 & $08-.59 .00 \mathrm{~N}$ & $37-48-00 \mathrm{E}$ \\
\hline 12 & $"$ & 20076 & West Shewa/Ambo & 2010 & $08-.58-00 \mathrm{~N}$ & $37-52-00 \mathrm{E}$ \\
\hline 13 & $"$ & 20077 & SNNP/Wenago & 1853 & $06-23-00 \mathrm{~N}$ & $38-20-00 \mathrm{E}$ \\
\hline 14 & $"$ & 20112 & South East Tigray/Inderta & 2000 & $13-29-00 \mathrm{~N}$ & $39-30.00 \mathrm{E}$ \\
\hline 15 & $"$ & 20117 & West Gojam/JabiTehnan & 1980 & $10-.39 .00 \mathrm{~N}$ & $37-24-00 \mathrm{E}$ \\
\hline 16 & $"$ & 20127 & West Shewa/Jibatnamecha & 2050 & $08-.58-00 \mathrm{~N}$ & $38-01-00 \mathrm{E}$ \\
\hline 17 & $"$ & 20133 & West Shewa/chelia & 1700 & $09-03-00 \mathrm{~N}$ & $37-10-00 \mathrm{E}$ \\
\hline 18 & $"$ & 20134 & West Shewa/Menagesha & 2600 & $09-11-00 \mathrm{~N}$ & $39-09.00 \mathrm{E}$ \\
\hline 19 & $"$ & 20146 & West Shewa/Jibat & 2200 & $08-.58 .00 \mathrm{~N}$ & $37-30-00 \mathrm{E}$ \\
\hline 20 & $"$ & 20165 & West Gojam/Bahirdarzuria & 1980 & $11-.25-00 \mathrm{~N}$ & $37-12-00 \mathrm{E}$ \\
\hline 21 & $"$ & 20166 & West Gojiam/Awi/Dangila & 1980 & $11-20-00 \mathrm{~N}$ & $36-58-00 \mathrm{E}$ \\
\hline 22 & $"$ & 21008 & West Gojiam/Awi/Dangila & 1980 & $11-20-00 \mathrm{~N}$ & $36-58.00 \mathrm{E}$ \\
\hline 23 & $"$ & 21012 & Arsi/Gedeb & 2380 & $07-.12 .00 \mathrm{~N}$ & $38-09-00 \mathrm{E}$ \\
\hline
\end{tabular}


Estimates of Heritabiliy, Genetic and Principlal Componente Analysis for Yield and its Traits in Ethiopian Mustard (Brasica Carinata A. Braun) Landraces

\begin{tabular}{|c|c|c|c|c|c|}
\hline 24 & 21017 & West Shewa/Gendbert & 2470 & $09-43-00 \mathrm{~N}$ & $37-46-00 \mathrm{E}$ \\
\hline 25 & 21026 & West Gojiam Awi/Dangila & 2000 & $11-18-00 \mathrm{~N}$ & $36-58.00 \mathrm{E}$ \\
\hline 26 & 21035 & West Gojam/Sekela & 2540 & $10-.50-00 \mathrm{~N}$ & $37-04-00 \mathrm{E}$ \\
\hline 27 & 21037 & West Gojiam/Awi/Dangila & 2165 & $11-.14-00 \mathrm{~N}$ & $36-51-00 \mathrm{E}$ \\
\hline 28 & 21068 & Bale/Adaba & 2500 & $07-01-00 \mathrm{~N}$ & $39-25-00 \mathrm{E}$ \\
\hline 29 & 21157 & SNNP /South omo & 2830 & $06-19-00 \mathrm{~N}$ & $38-52-00 \mathrm{E}$ \\
\hline 30 & 21225 & East Gojam/Enemay & 2000 & $10-.32-00 \mathrm{~N}$ & $38-09-00 \mathrm{E}$ \\
\hline 31 & 208411 & West Gonder/Debretabor & 2150 & $11-.50-00 \mathrm{~N}$ & $37-35-00 \mathrm{E}$ \\
\hline 32 & 229665 & West Gojam/Burie & 2050 & $10-33-00 \mathrm{~N}$ & $37-34-00 \mathrm{E}$ \\
\hline 33 & 237048 & Arsie-Robe & 2350 & $07-08-00 \mathrm{~N}$ & $40-00.00 \mathrm{E}$ \\
\hline 34 & 241907 & South Gonder/Fogera & 1825 & $12-.01-00 \mathrm{~N}$ & $37-43-00 \mathrm{E}$ \\
\hline 35 & 241910 & South Gonder/Farta & 2289 & $11-.49-00 \mathrm{~N}$ & $38-00-00 \mathrm{E}$ \\
\hline 36 & 242856 & Arsi zone /Sherka & 2360 & $07-32-64 \mathrm{~N}$ & $39-37-87 \mathrm{E}$ \\
\hline 37 & 242858 & Arsi zone /Sherka & 2360 & $07-34-27 \mathrm{~N}$ & 39-31-24E \\
\hline 38 & 243738 & South Wollo/Desiezuria & 2928 & $11-08-00 \mathrm{~N}$ & $39-13-00 \mathrm{E}$ \\
\hline 39 & 243739 & South Wollo/Tenta & 2950 & $11-.14-00 \mathrm{~N}$ & $39-15-00 \mathrm{E}$ \\
\hline 40 & 21256 & West Gojam/Bahirdarzuria & 1940 & $11-16-00 \mathrm{~N}$ & $36-59-00 \mathrm{E}$ \\
\hline 41 & 243750 & Wollo/kalu & 2020 & $11-45-00 \mathrm{~N}$ & $39-47.00 \mathrm{E}$ \\
\hline 42 & 2243756 & South Gonder/ Debark & 3115 & $11-.08 .00 \mathrm{~N}$ & $37-56-00 \mathrm{E}$ \\
\hline 43 & 243761 & Gonder Zuria & 2050 & $12-.19-00 \mathrm{~N}$ & $37-33-00 \mathrm{E}$ \\
\hline 44 & 243763 & South Gonder/Kemkem & 2070 & $11-57-00 \mathrm{~N}$ & $37-37-00 \mathrm{E}$ \\
\hline 45 & " 208556 & West Shewa/Adis Alem & 2200 & $*$ & $*$ \\
\hline 46 & 208585 & East Shewa/yerer & 1600 & $*$ & $*$ \\
\hline 47 & Yellow dodolla & Bale/Dodolla & 2500 & $06-.59-00 \mathrm{~N}$ & $39-12-00 \mathrm{E}$ \\
\hline 48 & (ZemX Yellow Dodolla ) & Cross & 2400 & 09-00-00N & $38-00-00 \mathrm{E}$ \\
\hline 49 & Local check & Holetta area & 2400 & 09-00-00N & $38-00-00 \mathrm{E}$ \\
\hline
\end{tabular}

Source: Holetta highland oil crops research program, *=information not found

\subsection{Experimental Design, Management and Season}

The experiment was executed from June 2013 to December 2013. The experiment was laid out in simple lattice design with two replications. A plot of four central rows each three-meter long and $30 \mathrm{Cm}$ spacing between rows were used for data collection. Each replication had seven blocks and each block was represented by seven plots. The path between blocks was $2 \mathrm{~m}$ and the spacing between plots with in sub-blocks was also $0.6 \mathrm{~m}$. Each entry was manually drilled a rate of $10 \mathrm{~kg} / \mathrm{ha}$ and urea and phosphorous fertilizers were applied at the rates of $46 / 69 \mathrm{~kg} / \mathrm{ha} \mathrm{N} / \mathrm{P}_{2} \mathrm{O}_{5}$ respectively following the national recommendations. All other recommended agronomic and cultural practices were carried out following practices described by Adefris(2005).

\subsection{Data Collected}

1. Days to flowering (Df): The numbers of days from date of sowing to a stage at which $50 \%$ of the plants in a plot open flowers.

2. Days to maturity (Dm): The number of days from date of sowing to a stage at which $50 \%$ of the plants have reached physiological maturity. It is the time when $50 \%$ of the capsules change their color into brown.

3. Seed yield per plot (SYPP): Seed yield per plot measured in grams after moisture of the seed was adjusted to 7 percent.

4. Oil content (Oc): The proportion of oil in the seed to total oven dried seed weight measured by nuclear magnetic resonance spectroscope as described by Oregon State University seed laboratory.

5. Thousand seed weight (Tsw): The weight ( $g$ ) of 1000 seeds from randomly sampled grains.

6. Oil yield (Oy): The amount of oil in grams obtained by multiplying seed yield per plot by corresponding oil percent.

7. Stand percent (SP): The proportion of plants at vegetative stage and at harvest as visually assessed in percentage. 
8. Number of Primary branches per plant $(\mathrm{PB})$ : The average number of primary branches per plant was counted from five randomly selected plants.

9. Number of Secondary branches per plant (SB): The average number of secondary branches per plant was counted from five randomly selected plants.

10. Plant height (PHT): The average height of five randomly selected plants was measured in centimeters from the ground surface to the top of the main stem at maturity.

11. Seeds yield per plant (SYPPL): The weight of the seeds of the five randomly selected plants measured in grams that are divided by five.

12. Leaf petiole length $(\mathbf{c m})$ : average measurements of the leaf petiole length from bottom, middle and top of five plants. From each leaf starting from base to the apex of the leaf blade excluding leaf part was measured at full vegetative stage.

13. Leaf length $(\mathbf{c m})$ : average measurements of the leaf length from bottom, middle and top of five plants. From each leaf starting from the base to the apex of leaf blade excluding petiole was measured at full vegetative stage.

14. Leaf width (cm): An actual measurement across the widest portion/section of the same leaf was at full vegetative stage.

15. Leaf area was measured using leaf area meter from bottom, middle and top of five plants for three leaf blade.

\section{RESULTS AND DISCUSSION}

The analysis of variance for the 15 traits studied is given in Table 2 . The analysis of variance showed that there were significant differences among genotypes for all traits compared. The significant difference indicates the existence of genetic variability among the accessions that is important for selection and breeding. Similarly Yared,(2010) studied thirty six genotypes of mustard for date of flowering, date of maturity, seed yield per plot, number of seed per plant, thousand seed weight, number of primary branches, number of secondary branches, plant height of traits found the same result. Besides, genetic variability of Ethiopian mustard for days to flowering and plant height has been reported by Getahun (1988) and Erena (2001) as well as days to maturity by Erana(2001).

Table2. Mean squares for different sources of variations for 15 genetic and morphological traits of Ethiopian mustard

\begin{tabular}{|l|l|l|l|l|}
\hline Characters & $\begin{array}{l}\text { Genotype } \\
(48)\end{array}$ & $\begin{array}{l}\text { Block } \\
(12)\end{array}$ & Replication(1) & $\begin{array}{l}\text { Intera-block } \\
(36)\end{array}$ \\
\hline Date of flowering & $141.98^{* *}$ & 6.39 & 0.91 & 9.96 \\
\hline Date of maturity & $284.69^{* *}$ & 45.67 & 84.5 & 44.36 \\
\hline Seed yield per plot & $503441^{*}$ & 925530 & 7543862 & 231667 \\
\hline Oil content & $3.4446^{* *}$ & $1.3825 \mathrm{~ns}$ & 217.51 & 1.1283 \\
\hline Oil yield & $108661^{*}$ & 167934 & 2098030 & 46331 \\
\hline Seed yield per plant & $18.2377^{*}$ & 15.9527 & 88.2551 & 9.6692 \\
\hline Thousand seed weight & $0.1939^{* *}$ & 0.06957 & 0.1111 & 0.06942 \\
\hline Stand percent & $208.34^{* *}$ & 721.28 & 4676.83 & 23.4813 \\
\hline Number of primary branches & $9.8346^{*}$ & 6.07095 & 24.7004 & 6.1063 \\
\hline Number of secondary branches & $0.3389^{*}$ & 4.0816 & 4.0816 & 0.2421 \\
\hline Plant height & $1004.12^{* *}$ & 1102.13 & 2812.5 & 169.46 \\
\hline Leaf Petiole length & $11.6242^{* *}$ & 2.7005 & 32.229 & 2.6565 \\
\hline Leaf length & $6.1553^{* *}$ & 2.072 & 22.6368 & 2.4629 \\
\hline Leaf width & $5.8638^{* *}$ & 1.8471 & 22.5408 & 2.1336 \\
\hline Leaf area & $7.3403^{* *}$ & 2.0052 & 25.0026 & 2.1764 \\
\hline
\end{tabular}

*, ** significant at $p=0.05$ and 0.01 significance level, respectively

\subsection{Heritability in the Broad Sense}

Breeders can make rapid progress where heritability is high by using selection methods that are dependant solely on phenotypic characteristics (e.g. mass selection). However, where heritability is 
low methods of selection based on families and progeny testing are more effective and efficient. Heritability estimated using the total genetic variance is called broad sense heritability. Heritability in the broad sense of the traits is presented in Table 4. In this study, heritability values were found to be sufficiently high for most important yield component characters. Dabholkar (1992) generally classified heritability estimates as low (5-10\%), medium (10-30\%) and high (30-60\%). Based on this classification, thousand seed weight $(68.80 \%)$, days to flowering $(65.91 \%)$, stand percent $(63.14 \%)$, days to maturity $(60.43 \%)$, plant height $(59.63 \%)$, seed yield per plot $(42.99 \%)$ and number of primary branches per plants $(34.20 \%)$ exhibited high heritability estimates. Thousand seed weight was found to be the most heritable trait in the genotype, with heritability of $68.80 \%$, followed by days to maturity $(65.91 \%)$ and stand percent $(63.14 \%)$. This indicates that selection for these traits in the genotype would be most effective for the expression of these traits in the succeeding generations. Therefore, good improvement can be made if some of these traits are considered as selection criteria in future breeding program. Similar findings had been reported by Yared (2010) for thousand seed weight, date of flowering, date of maturity and plant height. High heritability value for thousand seed weight, date to flowering, days to maturity plant height recorded in the current study was also recorded by Yared (2010) and Abebe (2006). According to Singh (1993), if the heritability of a character is high, selection for such character is fairly easy as selected character will be transmitted to its progeny. This is because there would be a close correspondence between the genotype and phenotype due to a relatively similar contribution of the environment to the genotype. At the same time secondary branches per plant (28.86\%), exhibit medium heritability estimates.

\subsection{Genetic Advance}

Concerning the genetic advance at 5\% intensity the highest genetic gain was predicted for seed yield per plot $(806.89 \mathrm{~kg} / \mathrm{ha})$ followed by oil yield $(378.38 \mathrm{~kg} / \mathrm{ha})$ and while the lowest genetic advance was predicted for thousand seed weight (0.43). Genetic advance as a percent mean ranged from $4.12 \%$ for leaf area to $57.18 . \%$ for petiole length (Table 3 ). Within this range, a relatively high genetic advance as a percent mean was observed for petiole length (57.18\%) and seed yield per plant $(56.65 \%)$ and followed by leaf width (48.63\%). On the other side high genetic advance with high heritability was shown for seed yield per plot and plant height in $\mathrm{cm}$ which may be because of the presence of both additive and non-additive gene action (Liang et al., 1972).Those traits having medium heritability along with high genetic advance could be improved using breeding procedure such as pedigree method. On the other hand, the lowest genetic gain as percent of means was observed for leaf area $4.12 \%$ followed by oilcontent $5.08 \%$. Low genetic advance as percent means observations in this study indicates that characters probably were under environmental influence than the genotypic expression and that selection based on these traits would be ineffective.

Table3. Broad sense heritability and genetic advance and Genetic advance as percent of mean of studied traits

\begin{tabular}{|l|c|c|c|}
\hline Character & h2b & $\begin{array}{l}\text { GA } \\
\text { k=5\% }\end{array}$ & GA/Grand mean *100 k 5\% \\
\hline Date of flowering & 65.91 & 14.36 & 15.39 \\
\hline Date of maturity & 60.43 & 20.24 & 11.26 \\
\hline Seed yield per plot & 42.99 & 806.89 & 40.37 \\
\hline Seed yield per plant & 39.18 & 4.75 & 56.65 \\
\hline Thousand seed weight & 68.80 & 0.43 & 14.36 \\
\hline Stand percent & 63.14 & 17.36 & 20.23 \\
\hline Number of primary branch & 34.20 & 3.35 & 30.10 \\
\hline Number of secondary branch & 28.86 & 0.59 & 17.81 \\
\hline Plant height & 59.63 & 37.97 & 20.96 \\
\hline Oil yield & 44.84 & 378.38 & 43.71 \\
\hline Petiole length & 56.03 & 4.06 & 57.18 \\
\hline Leaf length & 46.28 & 2.87 & 33.72 \\
\hline Leaf width & 48.29 & 2.82 & 48.63 \\
\hline Leaf area & 52.09 & 3.20 & 4.12 \\
\hline Oil content & 50.33 & 2.18 & 5.08 \\
\hline
\end{tabular}

$h 2 b=$ Broad sense heritability, $G A=$ Genetic advance and $K=$ Selection intensity 


\subsection{Principal Component Analyses}

In order to assess the patterns of variations, principal component analysis (PCA) was done by considering thirteen traits for seed yield and agronomic traits. Principal component analyses are presented in Tables 4. Principal component analysis showed that $88.18 \%$ of the variation was contributed by the first five principal components for agronomic traits. Leaf area, leaf length, leaf width, petiole length, days to flowering and days to maturity were the major seed yield positive contributors of the variation in the first principal component in which $39.5 \%$ of the variation revealed. Plant height, thousand seed weight, primary branches and stand percent had relatively high positive weight. Seed yield per plants and secondary branches had negative weight. Additional $24.1 \%$ variation in the second principal component was mainly observed through trait such as oil yield per plot, seed yield per plot and plant height. The third principal component was accounted for another additional $12.2 \%$ of the variation in which secondary branches was the major contributor. Thousand seed weight had the highest negative weight. Principal component 4 and 5 contributed $7.9 \%$ and $4.4 \%$ additional variations respectively. Thousand seed weight in principal component 4 and number of primary branches per plant in principal component 5 were among the major contributors. Primary branches per plant in principal component 4 and plant height in principal component 5 had the most negative weight. In general, it is assumed that traits with larger absolute values closer to unity within the first principal component influence the clustering more than those with lower absolute values closer to zero (Chahal and Gosal, 2002). In this study, most of the traits individually contributed small effects $( \pm 0.288-0.389)$ to the total variation and, therefore, differential grouping of genotypes was mainly attributed by the cumulative effect of the individual traits. However, traits which had relatively greater weight in the first principal component largely contributed to the total variation and they were accountable for differential grouping of genotypes.

Table4. Component scores of the first five principal components of 49 genotypes of Ethiopian mustard based on their agronomic traits

\begin{tabular}{|c|c|c|c|c|c|}
\hline \multirow[b]{2}{*}{ Traits } & \multicolumn{4}{|c|}{ Component scores } & \multirow[b]{2}{*}{$\begin{array}{l}\text { Principal } \\
\text { component } 5\end{array}$} \\
\hline & $\begin{array}{l}\text { Principal } \\
\text { component } 1\end{array}$ & $\begin{array}{l}\text { Principal } \\
\text { component } 2\end{array}$ & $\begin{array}{l}\text { Principal } \\
\text { component } 3\end{array}$ & $\begin{array}{l}\text { Principal } \\
\text { component } 4\end{array}$ & \\
\hline Date of flowering & 0.373 & -0.086 & 0.0226 & -0.123 & 0.093 \\
\hline Date of maturity & 0.356 & -0.211 & -0.177 & -0.067 & 0.127 \\
\hline Seed yield per plot & 0.005 & 0.483 & -0.216 & -0.134 & 0.254 \\
\hline Oil yield & 0.017 & 0.488 & -0.209 & 0.001 & 0.239 \\
\hline Seed yield per plant & -0.021 & 0.288 & 0.478 & 0.238 & -0.288 \\
\hline Stand percent & 0.084 & 0.413 & -0.215 & -0.182 & -0.025 \\
\hline $\begin{array}{l}\begin{array}{l}\text { Number of primary } \\
\text { branches }\end{array} \\
\end{array}$ & 0.102 & 0.041 & 0.506 & -0.362 & 0.692 \\
\hline $\begin{array}{l}\begin{array}{l}\text { Number of secondary } \\
\text { branches }\end{array} \\
\end{array}$ & -0.067 & 0.181 & 0.568 & 0.172 & -0.056 \\
\hline Plant height & 0.128 & 0.413 & 0.026 & -0.281 & -0.389 \\
\hline Thousand seed weight & 0.117 & 0.104 & -0.102 & 0.799 & 0.319 \\
\hline Petiol length & 0.407 & -0.050 & 0.086 & 0.052 & -0.085 \\
\hline Leaf length & 0.408 & 0.043 & 0.031 & 0.078 & -0.102 \\
\hline Leaf width & 0.417 & 0.032 & 0.030 & 0.019 & -0.085 \\
\hline Leaf area & 0.419 & 0.002 & 0.053 & 0.047 & -0.09 \\
\hline Eigen value & 5.53 & 3.37 & 1.71 & 1.11 & 0.62 \\
\hline Variance $(\%)$ & 39.53 & 24.10 & 12.20 & 7.94 & 4.41 \\
\hline Cumulative (\%) & 39.53 & 63.63 & 75.83 & 83.77 & 88.18 \\
\hline
\end{tabular}

\section{CONCLUSION}

In this study, 49 Ethiopian mustard genotypes acquired from diverse zones/regions of Ethiopia were evaluated in simple lattice design with two replications at Holetta Agricultural Research Center, West Shewa zone, with the objective of estimating broad sense heritability, genetic advance and principal component analysis for seed yield and its attributing traits in forty nine Ethiopian mustard land 
races. The analysis of variance showed the presence of highly significant differences among the tested genotypes for the all of characters considered, indicating the existence of genetic variability among the tested genotypes for these characters.

Heritability in broad sense estimates were high for thousand seed weight, days to flowering, stand percent, days to maturity, plant height, seed yield per plot and number of primary branches per plants exhibited high heritability estimates.

Similarly, only the heritability values of secondary branches per plant exhibited medium estimates. Genetic advance as percent of the mean (GAM) was high for petiole length, seed yield per plants, followed by leaf width and where as the rest shows low GAM below almost $45 \%$. Principal component analysis showed that $88.18 \%$ of the variation was contributed by the first five principal components for agronomic traits. Days to flowering and days to maturity were the major seed yield positive contributors of the variation in the first principal component in which $39.5 \%$ of the variation revealed. Additional $24.1 \%$ variation in the second principal component was mainly observed through trait such as seed yield per plot and plant height. The third principal component was accounted for another additional $12.2 \%$ of the variation in which secondary branches was the major contributor.. Principal component 4 and 5 contributed $7.9 \%$ and $4.4 \%$ additional variations respectively. Thousand seed weight in principal component 4 and number of primary branches per plant in principal component 5 were among the major contributors. However, traits which had relatively greater weight in the first principal component largely contributed to the total variation and they were accountable for differential grouping of genotype. Therefore these traits can serve as selection indices in genetic improvement of mustard yield and its component traits.

\section{REFERENCES}

[1] Abebe Delesa. 2006. Genetic Variability and Association Among Seed Yield and Yield Related Traits in Ethiopian mustard (Brassica carinata A. Braun) at Kulumsa, Arsi. An M.Sc. Thesis Presented to the School of Graduate Studies of Alemaya University. 75p.

[2] Adefris Teklewold. 2005. Diversity Study Based on Quality Traits and RAPD Markers and Investigation of Heterosis in Ethiopian Mustard. Ph.D. diss. Georg-August Univ. of Göttingen, Germany. 161p.

[3] Chahal, G.S. and S.S. Gosal. 2002. Principles and procedures of plant breeding: biotechnological and conventional approaches. Narosa Publishing House, New Delhi.

[4] CSA (Central Statistical Authority). 2013/14. Report on land utilization: Private peasant holdings, 'Meher' season. Statistical bulletin. Addis Ababa, Ethiopia.

[5] Dabholkar, A.R. 1992. Elements of biometrical genetics. Concept Publishing Company, New Delhi, India.431p.

[6] Doweny R.K. and G. RÖbbelen. 1989. Brassica Species. In RÖbbelen G, Doweny RK and Ahri A (eds) Oil crops of the world. McGraw-Hill New York. pp. 339-359

[7] EARO (Ethiopian Agricultural Research Organization). 2000. Crop Research Directorate, High land oil crops research strategy, Addis Ababa, Ethiopia.

[8] Erena Aka. 2001. Kulumsa agricultural research center highland progress report for the period 2001.

[9] Getahun Mulat. 1988. Diversity of Brassica species in Ethiopia with especial emphasis on Brassica carinata. In: Oil Crops News Letter. No. 5. The IDRC Oil Crops Net Work for East Africa and South Asia, IAR, Addis Ababa, Ethiopia.

[10] Getinet, A. and A. Nigussie. 1997. Highland Oil Crops: a two decade research experience in Ethiopia. Research report No. 30. Institute of Agricultural Research, Addis Ababa, Ethiopia. 30p.

[11] Goyal SN and S Kumar, 1991. Combining ability for yield component and oil content in sesame. Indian J Genet Plant Breed, 51: 311-314.

[12] Gomez-Campo, C. and S. Prakash. 1999. Origin and domestication of the Brassica. pp. 33-58. In: GomezCampo C (ed.). Biology of Brassica Coenospecies. Elsevier, Amsterdam.

[13] Hemingway, J.S. 1976. Mustards Brassica species and Sinapsis alba (Cruciferae). In: Evolution of Crop Plants. N.W. Simmounds (ed.) Longan. London. 339p.

[14] Liang, G.H., C.R. Reddy and A.D. Dayton.1972. Heterosis, inbreedign depression and heritability estimates in a systematic series of grain sorghum genotypes. Crop Sci. 12(4):409-411

[15] Nigussie Alemayehu. 2001. Germplasm diversity and Genetics of Quality and Agronomic Traits in Ethiopian Mustard (Brassica carinata A. Braun). Ph.D. Thesis, George-August University of GÖttingen, Germany 
[16] Nigussie Alemayehu and Mesfin Abebe. 1994. Relative importance of some managmnet factors in seed and oil yields of Ethiopian mustasrd (Brasica carinata Braun.) and Rapeseed (Brasica napus L.). Ethiop. J. Agric. Sci. 14: 27-36

[17] SAS Institute INC., 2002- 2008. SAS*STAT, users guide, version 9.2, Cary N.C., SAS INC

[18] U.N. 1935. Genome analysis in Brassica with special reference to the experimental formation of B. napus and peculiar mode of fertilization. Jpn. J. Bot. 9: 389-452

[19] Yared Semahegn. 2010. Genetic diversity and Relationship among Association amongEthiopian mustard (Brassica carinata A. Braun) genotypes based on their agronomic and quality Traits in at Holetta Agricultural research,. An M.Sc. Thesis Presented to the School of Graduate Studies of Jima University.75

Citation: Fekadu Amsalu, "Estimates of Heritabiliy, Genetic and Principlal Componente Analysis for Yield and its Traits in Ethiopian Mustard (Brasica Carinata A. Braun) Landraces" International Journal of Research Studies in Agricultural Sciences (IJRSAS), 2020; 6(4), pp. 17-24,http://dx.doi.org/10.20431/2454-6224.0604003

Copyright: (C) 2020 Authors. This is an open-access article distributed under the terms of the Creative Commons Attribution License, which permits unrestricted use, distribution, and reproduction in any medium, provided the original author and source are credited. 